\title{
Researching Kedah's Malay Heritage Food Tradition and Eating Culture
}

Noriza Ishak, Anida Ismail, Mazni Saad, Adilah Md Ramli

To Link this Article: http://dx.doi.org/10.6007/IJARBSS/v11-i16/11224 DOI:10.6007/IJARBSS/v11-i16/11224

Received: 09 July 2021, Revised: 12 August 2021, Accepted: 24 August 2021

Published Online: 16 September 2021

In-Text Citation: (Ishak et al., 2021)

To Cite this Article: Ishak, N., Anida Ismail, M. S., \& Ramli, A. M. (2021). Researching Kedah's Malay Heritage Food Tradition and Eating Culture. International Journal of Academic Research in Business and Social Sciences, 11(16), 140-154.

Copyright: (C) 2021 The Author(s)

Published by Human Resource Management Academic Research Society (www.hrmars.com)

This article is published under the Creative Commons Attribution (CC BY 4.0) license. Anyone may reproduce, distribute, translate and create derivative works of this article (for both commercial and non-commercial purposes), subject to full attribution to the original publication and authors. The full terms of this license may be seen

at: http://creativecommons.org/licences/by/4.0/legalcode

Special Issue Title: Contemporary Issues in Tourism and Hospitality industry, 2021, Pg. 140 - 154

Full Terms \& Conditions of access and use can be found at http://hrmars.com/index.php/pages/detail/publication-ethics 


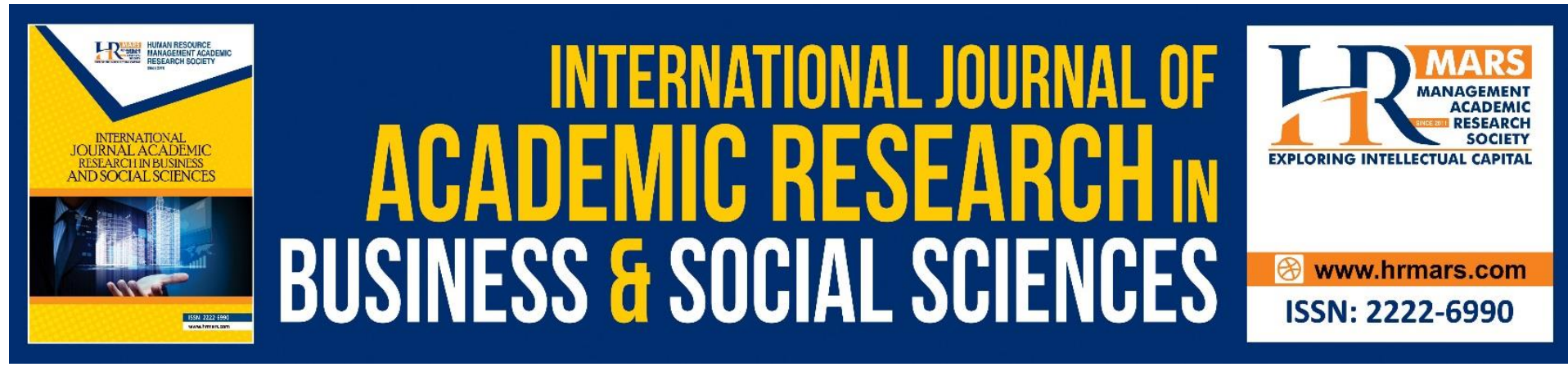

\title{
Researching Kedah's Malay Heritage Food Tradition and Eating Culture
}

\author{
Noriza Ishak ${ }^{1}$, Anida Ismail ${ }^{2}$, Mazni Saad ${ }^{3}$, Adilah Md Ramli ${ }^{4}$
}

${ }^{1}$ Department of Culinary Arts and Gastronomy, Faculty of Hotel \& Tourism Management UiTM, Puncak Alam, Selangor Malaysia, ${ }^{2}$ Department of Culinary Arts and Gastronomy, Faculty of Hotel \& Tourism Management UiTM, Pulau Pinang, Malaysia, ${ }^{3}$ Department of Tourism, Kulliyyah of Languages and Management, International Islamic University Malaysia, Edu Hub Pagoh, Muar, Johor, Malaysia, ${ }^{4}$ School of Food Science and Nutrition Universiti Malaysia Sabah, Kota Kinabalu, Malaysia

Email: noriz267@uitm.edu.my

\section{Abstract}

This paper presents findings from a study carried out through a qualitative study investigating the various types of Kedah food heritage. A snowball approach was used to collect data from four families in Kuala Nerang, Pendang, and Alor Setar within nine days. Eleven types of food were then grouped into breakfast, main dishes, and snacks/delicacies. The data revealed this food would be able for consumption at any time. The villagers continue to consume the same traditional foods that their families used to cook. These results highlighted the importance of sustaining the preparation of heritage food in coping with the lost identity of the food. This study suggests that the Heritage Department includes the identified foods into the list of National food heritage to preserve these foods as part of the food sustainability initiatives.

Keywords: Food Preparation, Kedah Heritage Food, Practices, Sustainability, Eating.

\section{Introduction}

Food is an integral part of cultural tradition. The need in preserving food heritage is of concern at the national level. Often, Malaysians are cooking and consuming heritage food, yet the food preparation is gradually losing its original values due to many factors. Among the factors are the current situations that require a long time to prepare the food due to time constraints among the working women. The inaccessibility of fresh ingredients for those staying in the city area may add to the reasons. What constitutes heritage food? The Malaysian Department of National Heritage (2016) cited heritage food as food identified to an ethnic race for its ingenuity and uniqueness. The assortment of this heritage food is favoured for its taste, texture and aroma, catering to the localised palate. It is often passed down from one generation to the next by oral communication rather than proper documentation.

The origins of heritage food are due to the fruit of a society's predecessor era, which laid the foundation for an intangible cultural inheritance with the utilisation of available natural resources in pursuit of survival (Maclean et al., 2007). In another perspective of Bessière (1998), food heritage can be one of the aspects in attracting tourists to come to their place. 
It is suggested that heritage is a central dimension that needs to be more specifically discussed (Kapelari et al., 2020). The United Nations World Tourism Organization (UNWTO) reported that food heritage has evolved as among the nation's top segments of the cultural tourism industry, considering the diverse existence of the global cultural tourism market. According to Alonso and Krajsic (2013), it is also vital for people who are not staying in their homeland as the food would be the chain between them and their true identity.

As for Malaysia, Tibere and Aloysius (2013) informed that if the country needs to preserve its attractiveness as a food haven destination of choice, it is essential for the government to have a supporting policy and prepare a system that will lead to the preservation of its food heritage as a cultural tourism commodity. Food heritage has been numerously discussed in previous studies and papers on its importance in human life. Stubbs (2010) said that the significance of cultural heritage goes further than recognising the local distinctiveness that people identify with the crucial aspects of their geographical community. Food heritage is valued as the uniqueness of one's culture and tradition. People need to try and preserve it. Kapelari et al. (2020) conveyed that the advent of socio-cultural food criteria and the notion of food history are core factors that affect what, when and how people want to consume these foods.

However, the continuity and preservation of heritage food have a set of its own challenges in the modern world as globalisation has impinged on the traditional forms of everyday life (Mardatillah et al., 2019). Choices such as the 'fast food' in the likes of MacDonald's and KFC are taking over in the developing world; hence, diminishing the interest in heritage food further (Yadav, 2020). The charm of heritage food is also compromised due to the disconnection of the feelings of the young generation as they are not familiar with or not attracted to the food compared to the contemporary selection available. Although the importance of heritage cuisine is becoming more significant, the concept of heritage food remains unclear, and there is still a scarcity of information on heritage food (Almansouri et al., 2021). The current study explored the heritage foods in Kedah and investigated if food dishes have continuity from ancestors to the present generation. Malay heritage foods in Kedah were chosen because the initial findings showed that the heritage food is still being prepared these days within the Kedah Malay society. Besides, Kedah's food is considered unique as the diet may be influenced by traders who landed at Kedah's essential ports. The traders who came and resided in Malaya may bring their background and heritage of food preparation with them.

\section{Literature Review \\ History of Kedah and its Food}

Back in the days, Kedah, previously known as Kedah Tua, used to be the last port of call for voyagers who came to and from Malacca before continuing the journey across the Bay of Bengal to India and otherwise (Muhammad et al., 2016). The location of Kedah Tua port, situated at Gate Strait of Malacca and the Bay of Bengal and the East Coast of India, has become the selection of Indian merchants in terms of trade compared to other Malay ports in the Archipelago. This is because the location of Kedah is at the junction of India and China with the east and west axes (Kuroda, 2015a). The port has become a place where ships would stop to get food supplies and water and repair broken boats. Hakimi (2006) learnt that it indirectly turned the Malay sailors as intermediaries between traders from western India and Chinese traders on the east side. Lembaga Muzium Negeri Kedah (2020) stated that Barbosa, a Portuguese author who wrote in 1516, mentioned that Kedah was a trading centre for 
different goods. Arab ships have come to trade from different countries. There are also black peppers brought to China from Melaka in Kedah. Nowadays, Kedah is known as the rice bowl of Malaysia since the main activities that contribute to the country's economy is cultivating rice fields (Halid, 2016).

Thailand, also known as Siam, demonstrated to be the most noteworthy power that Kedah has had a connection with as it has a great impact on the future of that state besides the British. Kedah has also significantly been influenced by Thailand. Both countries are located next to each other, and they were a tributary kingdom of Siam until the Anglo-Siam Treaty of 1909 (Tokoro, 2015). As for now, the relationship of Kedah and Thailand is regarded as "border districts' ' by the national capitals of Kuala Lumpur and Bangkok, under the new nation-state structure (Kuroda, 2015b). This is because the district of southern Thailand bordering the north of Kedah counts the majority of Buddhists which house many Buddhist cities and temples like Nakhon Sii Thammarat. As a result of the relationship, Kedah had to sporadically give Bunga Mas (Golden Flower) to Bangkok, Thailand (Ahmat, 1957).

Kedah relies heavily on agriculture as its main economic activities because of its mother nature. According to Mahmud (1969), evidence showed that paddy crops were first planted in the state of Kedah during the 15th and 16th centuries, or maybe much earlier. It is reported by Braddel (1989) that Kedah was once referred to as Gedda, a word that came from Hindi which is Khadar, meaning suitable soil for rice cultivation. This shows that Kedah has been well-known for its rice productions. River valleys have developed since the Kedah Tua kingdom was founded and used as a rice-growing region (Mahmud, 1969). Now, the state of Kedah is responsible for almost all of the rice production and supply in Malaysia. Due to that, Kedah is known as the rice bowl of Malaysia (InfoMalaysia, 2016).

\section{Heritage Food}

Heritage can be described as a symbol of specificity since it describes similarities and distinction that can be used as the ethnic origin's trademark (Bessière, 2013). Since it is solely the object of restoration (Davallon, 2002), heritage has been a venue for initiatives and mobilisation. Bessière (2013) also stated that heritage is primarily described as a set of material and symbolic elements; it encompasses the modes of life of a particular group and types of social organisation. Kedah heritage food has taken place pretty early and has continued to evolve during the trading years, gaining significant influence from nearby nations (Brissenden, 2003). It is also hypothesised that Malaya food was created earlier than the 13th century and produced continuously during trading years as it gained significant influence from Thailand and Indonesia. Ling (2012) claimed that Malay food was recognised as a signature similar to hot and spicy flavour. Since Tanah Melayu is located between several countries, it has influenced the locals' life, including food.

Ling (2012) reported that the food in northern areas such as Penang, Perlis and Kedah, similar to Thailand, have a distinct similarity to a blazing hot, spicy and sour taste. Previous papers have also discussed the understanding of Kedah heritage food. Smith and Akagawa (2008) described Kedah heritage food as a mixture of practicality and knowledge that includes the skills, planning, and processing techniques practiced for centuries. Zahari et al. (2013) asserted that heritage food is a process on the conversion of expertise, planning, and cooking methods that provides a person with the capability to prepare healthy and culturally 
acceptable food. Gulai batang pisang, called gulai rias pisang is famous mainly in Baling area (Itawrah, 2020). In Kedah, since it is famous for its agriculture, most of the food would be created based on its availability, such as gulai batang pisang. This is because planting banana trees is commonly practiced in Baling especially in the rural area; hence, the banana tree is used to cook the food during weddings.

Some researchers identified the essential elements of the food. Rozin (2006) proposed three attributes of food that distinguish itself from each ethnic group such as Chinese and Indian which are (a) essential ingredients, (b) flavourings concepts (lemongrass, ginger, chilies, dried herbs and spices) and (c) cooking methods. According to Trichopoulou, et al., (2006), AGROCERT(Agricultural Products Certification and Supervision Organization) has suggested the conditions of the food to be recognised as heritage food which are (a) the use of old-style raw materials in the past which is still known based on geographical sources; (b) conventional preparations or ingredients passed down from generation to generation, and (c) Kedah heritage food manufacturing and/or processing methods passed down from generation to generation through oral training or other practices. If the previous criteria are met, the food can be acknowledged as heritage food. Thus, this study is necessary to be conducted as it highlights the food that considers the practice held dearly by the Kedahan. Much can be achieved by uncovering the Kedah state treasures.

As Saad et al (2021) suggested, more areas of heritage food study must be conducted to boost and improve the level of understanding on the consumption of heritage food. This is in line with Hamzah et al. (2013) who highlighted the abundance of local resources in this country which allows for the creation of rich, savoury, and unique dishes. Some even had a story and history behind them, which became more widespread as more people used it to acknowledge the culture (Ting et al., 2017). Traditional meals are used as a point of contact (Rearick, 2009) which enhances social ties and frequently provides spaces for interaction or communication (Smith et al., 2020); for example, during the preparation, presentation and consumption of foods. Smith et al. (2020) explained the idea that developing a family structure is based on parents and their descendants sharing their meals. Traditional cuisine and customs link people together in the family by sharing it, enjoying the family relationship with each other (Debevec \& Tivadar, 2006) and binding people in various areas of the world together (DiPiazza, 2004).

Therefore, while visiting the state, Kedah's historic kitchen may be savoured. There is only one place considered as a window to explore food in Kedah. Pekan Rabu is the only premise that well presents, if not all, most of the heritage food to the locals and outsiders. It is a very well-known place for tourists and locals to go and find various Kedah's Kedah heritage food (Tourism Malaysia, 2014). It was first opened at Tanjung Chali, Alor Setar in 1930 and founded by the prince of Kedah named Tunku Yaakob Abdul Hamid (Noor, 2020). People can find most of Kedah heritage foods there as it offers variety of food such as heritage biscuit, serunding (chicken/meat floss), dodol (delicacies made from glutinous rice and coconut), rojak paste, garam belacan (dip for fruits) and many more (Tourism Malaysia, 2014). Most of the foods are sold at a reasonable price. However, Pekan Rabu is not only famous for its food choice. This place is indeed a place that offers the insights of Kedah at one stop destination. 


\section{Methodology}

Qualitative approaches through observations and interviews were used in this study. Qualitative studies strongly advocate the cultural and social values attributed to food and the notion of food as cultural heritage and specifically, the most important categories that emerged from the qualitative study regarding the role of food as cultural heritage (Kapelari et al., 2020). Since this study focused on gaining knowledge about Kedah and its heritage food, observation was used. Observation method is considered as the most appropriate method recommended by Given (2008) since observation can be seen as one of the earliest known and most fundamental research process methods. This technique involves gathering evidence using one's senses, in particular seeing and hearing routinely and meaningfully. This study also followed Werner and Schoepfle's (1987) approach who believed that when doing observation, one must follow the processes or procedures which are (a) descriptive observation, including observation of all, in which the researcher assumes a beginner mentality by believing little information and taking nothing for granted; (b) oriented observation, in which such entities are considered meaningless and may therefore be overlooked, and the researcher typically focuses on well-defined, measurable entities; and (c) limited observation, in which redo is considered meaningless.

Also, a camera was used as the tool for data collection. The photographs were considered data that were taken as evidence in the study. They were used to study the perception of Kedah people by revealing the food heritage practice in their food preparation. In the process of observation, the researchers only observed without directly participating in it. Notes were taken throughout the observation to capture important points and behaviours. In addition, further information needed was obtained by interviewing the participants. The samples of this study were women who prepared the heritage food in Kedah. Women as samples are the most preferred because traditionally, they were the ones who mostly ended up preparing the food at all times (Bianchi et al., 2000), even though it was argued that the trends are shifting in recent years (Smith et al., 2013).

The criteria set for the informants of this study are that they have experience with the cooking and familiar with the dishes. Therefore, women aged above 35 were considered as the most suitable participants for this research. This age is believed to have a vast experience, especially in the perspective of cooking heritage food. Their information through experience is more accurate; thus, they will confirm the types of heritage dishes that have been practiced before and at present. A short and non-formal interview was also conducted for deeper understanding. A snowball approach was used to collect the data from four families at Kuala Nerang, Pendang, and Alor Setar within nine days in June 2020. The interviewees were contacted through a phone call. Once the permission was granted, the interview was conducted in early June 2020. The interview and engagement for taking pictures took approximately 3-7 hours, depending on the cooking prepared by the host. The interviews were recorded, transcribed, and analysed through a process of using thematic transcription. Food heritage respondents then validated the results.

\section{Result and Analysis}

Findings revealed eleven types of Kedah food during the data collection. The foods are then categorised into breakfast food, main food, and snacks/delicacies. The study's findings can help the researchers comprehend some fundamental practices of these heritage cuisines. The researchers categorised the findings into three groups. However, it was considered that there were no rules involved when the food was served as informed by most of the informants. 


\section{Category 1 - breakfast food/teatime}

A heritage food that is considered as the all-time favourite for the Kedahan is sticky rice mango (figure $A 2$ ) or pulut mangga. This heritage food has a Thai influence. This is justified as nations (Brissenden, 2003) mentioned that some cooking has significant influence from the neighbouring countries. As the Thais use it as dessert, the Kedahan take this food during breakfast or any time that mango is available. In Kedah, most of the houses plant a chokanan variety mango tree, and when there is a season where mango supply is available, they will prepare the dish. This dish consists of steam glutinous rice added with coconut milk while the glutinous rice is still very hot. The thick coconut milk is stirred into the rice until a shiny texture is formed and served with fresh and ripe sweet mango. The taste of creamy glutinous rice and the sweetness of mango provide a great combination. The first informant (73 years old lady) confirmed that the food could be taken at any time, and sometimes during feasting, they serve this food as a main dish.

She added that another very popular food among the Kedah community is ketupat daun palas (Figure A3), or glutinous rice stuffed in fan palm leaves. It is a type of dumpling made from glutinous rice cooked with coconut milk and packed inside a triangle-shaped palm leaf pouch. The food has been familiar to Kedahan since a long time ago. Previously, this type of dish can only be found during the festival, but these days it is available throughout the year. It takes several hours to cook this dumpling because the water used to boil the dumpling needs to be totally dried up, leaving dried rich greasy dumpling. The taste of the cooked palas leaf gives a solid fragrance to the dumpling. According to the informant, in this ketupat making, coconut milk in a packet is sometimes used to replace the original coconut milk. Interestingly, even santan sawit (palm milk) is widely used in this product making and other products.

Another dish evident is steamed glutinous rice eaten with salted fish (Figure A1), and grated coconut. It is a heritage food that can be seen during breakfast among the community. This food is usually eaten by farmers while working at the paddy fields. Before enjoying the special dish, the grated coconut is mixed simultaneously with glutinous rice and a piece of fried salted fish.

\section{Category 1 - breakfast food/tea time}

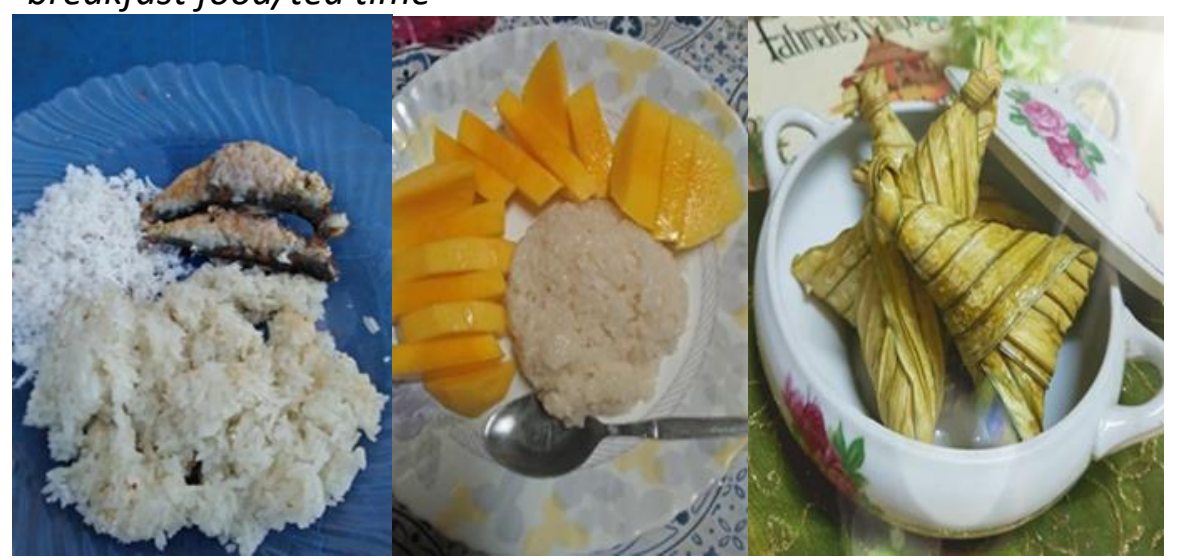

Figure A1

Figure A2

Figure A3 


\section{Category 2- main food}

Another type of finding in this category is nasi ulam (Figure A5). An informant from the third family explained that this heritage cuisine is usually prepared during Ramadan and for other special occasions or just eaten on other regular days. Malay mixed herb rice or nasi ulam is a cooked rice tossed with various finely cut herbs commonly found in Kedah. According to the informant, hundreds of herbs and plants are used in the nasi ulam making. However, due to some herb's extinction, herbs for nasi ulam may be limited to those in their surroundings. Kesum leaves, lemongrass, ginger, ginger leaves, galangal, kadok leaves, pegaga leaves, selom leaves, turmeric leaves, cekur leaves, kaffir lime leaves, cashew or janggus leaves, ulam raja, curry leaves, kantan or torch ginger flowers, asam gelugur leaves, sekentut leaves, tenggek burung, bebuas, putat shoots, mint leaves, basil leaves, cemumar leaves, cekur leaves, lemuni leaves and mengkudu leaves are some of the herbs found in this food. According to the informant, the herbs are usually planted in the backyard and/or around the house. The herbs being used are especially those fragrant herbs with some spices and fried dried fish that have been pounded into floss. Small leaves are wrapped with large leaves to ease the slicing process. This type of rice is best served with asam pedas batang keladi. This combination is like a twin that must come together whenever the rice is prepared. The informant added that the older generation truly loves this type of rice. However, nowadays the younger people have learned to appreciate the dish. This happens when the meal is the only food prepared and the youngsters have no choice but to try it and at the end, they acquire the taste.

She further explained that asam pedas batang keladi (Figure A5) (boiled yam stems in sour sauce) is a simple hearty dish that is quick to make. Yam stem and yam tuber are first cleaned while the outer layer of the stem is removed. Then it is blanched in hot boiling water. The yam is then cooked with grounded dried chilies, belacan (shrimp paste) anchovies and tamarind slices to add the sour taste. The sourness gives an excellent complement to nasi ulam. Again the supply of this cooking is found around the house or the neighbours' yard of that vicinity.

Even though this cooking was not done on the day of the visit, Madam Ain (57-years old) told the researcher about another specialty known to most Kedahans: gulai daging rias batang pisang or beef curry cooked with banana stem. It is a heritage beef curry made from the edible pith found in the trunk of a young banana tree, and it is a specialty in the north during a wedding celebration. It is often cooked with beef and can be considered a rare dish that is hard to find in a restaurant, particularly in urban areas. This information was gathered through the interview session since no cooking demonstration was done because the main ingredients were not available.

Another interesting heritage food that was prepared and explained by the informant was Haruan Bantut (Figure A4). It is grilled ikan haruan (snakehead fish) stuffed with spicy grated coconut. This dish is popular during the harvesting season. At the time of the observation, the supply was available, so the dish was evident. Based on the information from the informant, the cooking commonly uses a large snake head fish that weighs more than three kilograms. The bland taste of the fish is restored with the fragrant of spicy grated coconut. But on this occasion, only medium size fish was available. The fish was cooked without removing the scales. The back of the fish was cut and cleaned with lemongrass leaves 
to remove the fishy smell and slimy substances. Then the fish was coated with salt and turmeric powder. Grated coconut was then mixed with grounded turmeric, chilies, lemongrass, and onion which were later stuffed into the fish. To prevent the grated coconut from coming out during the process, bamboo or coconut branches were used to place the fish. Usually, this grilled fish is served together with hot white rice.

\section{Category 2- Main Food}

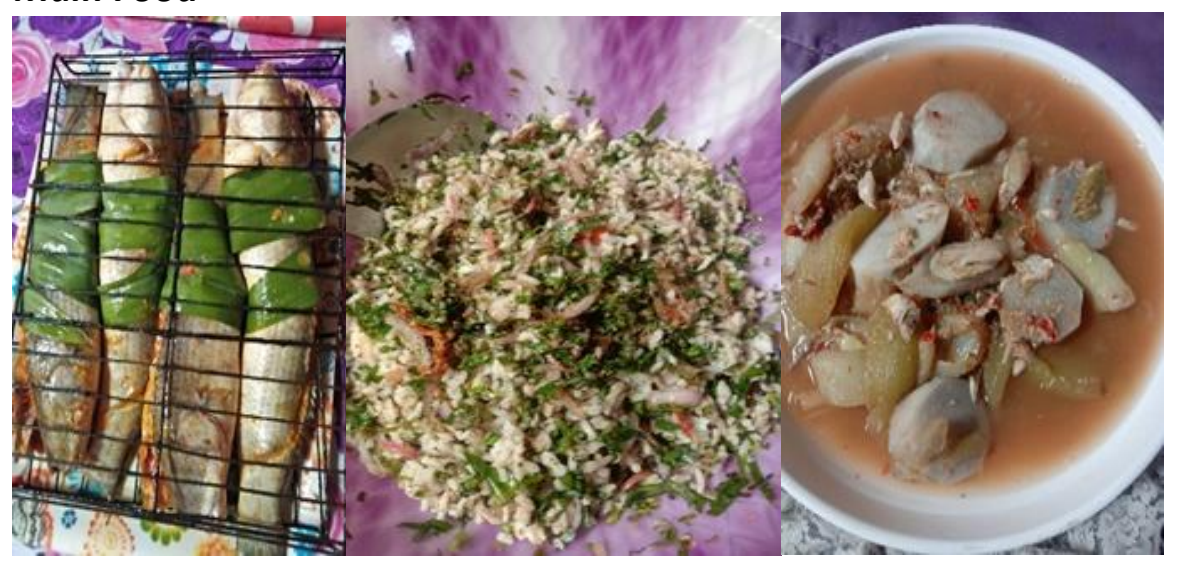

Figure A4

Figure A5

Figure A6

\section{Category 3-snacks / delicacies}

Another dish discovered during the observation was wajik (Figure A7) or sticky rice in palm sugar. It is a Kedah diamond-shaped dessert or heritage snack made with steamed glutinous rice and further cooked in palm sugar, coconut milk and pandan leaves for fragrance. Based on the information given by a woman ( 56 years old) from the second family interview and observation session, there are two types of wajik. One is cooked with brown sugar and the other with white sugar and rose syrup. The most common and usually served is the brown wajik. Cooking wajik is a very tiring task. She further explained that making wajik is a tradition used as an organised event among the neighbours. This is done during weddings, engagements and even 'Eid celebrations.

Kuih serabai (Figure A8), or coconut yeast cake, is simple and easy to make. This cake is made from rice flour. The food is then kept for 2-3 hours before cooked into thin pieces (like pancakes) and eaten with palm sugar gravy. As informed by the informant, this cake is rarely sold at cake shops except during Ramadan. It is a popular cake in Kedah and commonly served after the funeral of the deceased. Another evident delicacy was banana cake or Lepat pisang (Figure A9) in Malay. The way this steamed sweet delicacy is prepared requires wrapping and folding using the banana leaf. It is then steamed for twenty minutes. There are many different types of lepat in Kedah that are usually made from banana, pumpkin, cassava or corn. As explained, among all, banana lepat is the most common. Lepat liat (Figure A10) is also another famous Kedah heritage delicacy. The cake uses glutinous rice flour, and it is very popular among the older generation. This delicious food is sweet with sticky texture like dodol.

Based on the observation of the third family, famous sweet delicacies were seen. Madam Salmah, an informant from the third family, elaborated that dodol (Figure A11) is a sweet and sticky concoction made from coconut milk, jiggery and sticky rice flour. The best 
dodol is characterised by its soft or dense texture. Dodol is prepared for various occasions and usually comes with brown sugar and coconut flavour. Factory-made variation is also popular among Kedahan, and it can be purchased at Pekan Rabu, Alor Setar. The history and origin of dodol are unclear, but one of the informants claimed that it is one of the oldest desserts found in Kedah.

\section{Category 3-snacks/delicacies}

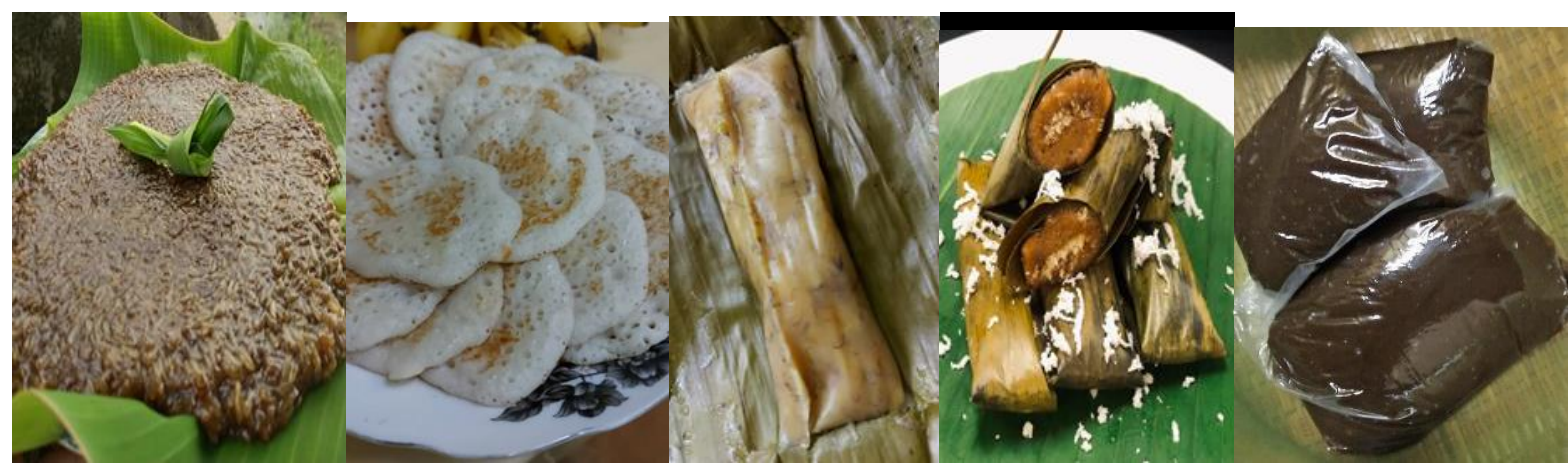

$\begin{array}{llll}\text { Figure A7 } & \text { Figure A8 } & \text { Figure A9 } & \text { Figure A10 }\end{array}$

\section{Discussion}

Several studies have shown that heritage food refers to the physical chunk used to prepare food and consumption (Almansouri et al., 2021) that is important for rural areas as it is strongly related to villager's identity, and specifically, to food production. Almansouri et al. (2021) emphasised that heritage food reflects shared memory and origins, which support a feeling of belonging to a territory, how the dishes are prepared, and who prepares them. This also includes preparation, ingredients, recipes, and the context, such as serving and presenting the food. As for the finding of this study, the villagers continue to consume the same traditional foods that their families used to cook. This finding supported by Rahman et al. (2018) stated that the knowledge of traditional food preparation was transmitted with the young generation from the older generation within the family. These results highlighted the importance of sustaining the preparation of heritage food in coping with the lost identity of the food.

The findings also revealed that the food provided in this study is not limited to the category as defined by the researchers. All informants agreed that Kedah heritage food is rarely categorised into breakfast, main course, and afternoon tea as typically expected in western food. They said that the food can be prepared and enjoyed anytime, depending on the availability of the ingredients. As mentioned by Madam Sham (65 years old), "there is no specific time to eat.... that means you can just eat in the morning or evening ... For example, steamed glutinous rice served with mango or durian ... can be eaten in the morning ... noon or night". Moreover, working in the paddy fields often requires total energy; thus, heavy food like glutinous rice is the best choice. The farmers often bring food such as pulut ikan masin and pulut inti to the paddy fields as their lunch. They may also have consumed it as breakfast at home. The other family members enjoy the food together at work or home and gradually become accustomed to the food. 
The informant would also inform that the food for snacks can also be eaten during breakfast (Figure A7, Figure A8, Figure A9, Figure A10, Figure A11), at teatime (Figure A1, Figure $A 2$, and Figure $A 3$ ), food lunch (Figure A4, Figure A5, Figure A6) or dinner (Figure A4, Figure $A 5$ and Figure A6). That would be the same for the food such as items in Figure $A 6$ and A2 which can be served to families and guests whenever they have it. The results also demonstrated that the cuisine was served within the respondent families more than a decade ago and then copied from their parents and relatives. The memory they had towards the food confirmed the existence of the cuisine. Some of the food items are also familiar and commonly found in other states in Malaysia or country for example ketupat palas also can be found in Sarawak (Sahari et al., 2018), dodol is one of traditional foods in Pahang (Abdullah et al., 2020). While in Indonesia, there are various types of ketupat that can be found in each region (Rianti et al., 2018).

In sum, the food preparations play an important role in the possible sustainability of the practices, which consistent with Rahman et al. (2018) statement that the role of family in sustaining the Malay traditional food is important in influencing and shaping the young generation's eating behavior. They also learn to prepare Malay traditional food at home with their family. While, it is important to understand the food terminologies and knowledge on Malay ingredients, preparation, equipment, and cooking method from generation to generation as it is the effective way in achieving preservation (Abdullah et al., 2016).

Available ingredients/sources and the way of packaging of some food items give a significant role in identifying the identity of cuisine with ethnic as it is representing as an image of a region which consistent finding from Rianti et al. (2018) and Sahari et al. (2018). The food however it may serve at special events as mentioned by Rianti et al. (2018) identified that ketupat is served during religious celebrations such as Eid Al-Fitr. While Muhammad, Zahari, et al. (2015) state the ideal time to transmit the knowledge of traditional food is during celebrations and religious festivals. In other hand, Muhammad, Karim, et al. (2015) found that school activities such as cultural event and festive season may attract boys more than girls. Thus, it is important to introduce traditional food not just during festivals but also instill in the school activities to promote awareness of the traditional food.

\section{Conclusion}

In conclusion, Kedah heritage food is effectively appreciated by the Kedah community. Availability of the ingredients also eases the preparation of the raw material. Since Kedah heritage food may have similarities with the neighbour's state like Penang as it was part of Kedah before the colonisation, potential research could document the same research in other states of Malaysia. This study also indicates the importance of preserving the values of heritage food in Kedah mainly. It shows that Kedah's heritage food is a crucial part of food heritage culture, thus requiring integrative commitment from all stakeholders to ensure the sustainability of the culture. In addition, due to a lack of information about the unique food heritage in Kedah state, much of the food is unknown to outsiders, and even locals have very little awareness of it. An effort must be made to have some of the food recognised in the National Heritage Department. There are various ways, opportunities, and room for improvements that are readily available for the government, non-government bodies and citizens to promote the cuisines. This includes a combination of strategies from various parties, such as the education ministry, agriculture, fisheries, tourism, village heads, and art 
makers to channel the necessary materials so that they are always sufficiently available. Dissemination of information on heritage foods should be aggressively done by the government and other responsible authorities virtually and offline to ensure the information of the food reaches the people. Gastronomic tourism is an example of how the sustainability of food could be achieved. More Kedahans should be encouraged to participate in this field, particularly in culinary heritage-based businesses, so that the production of the cuisine is ongoing and may reach the understanding and acceptance of a large number of people. Misiura (2006) suggested that there has been an increase of interest and demand for foods and beverages that are grown and offered in traditional ways in many countries.

Kedah culinary heritage should also be further investigated through studies involving diverse stakeholders with different topic areas through empirical evidence. The preservation of heritage food also starts from home and an early awareness of its importance will confirm survival of this sustenance; thus, preventing it from becoming extinct over time. As suggested by Brulotte and Di Giovine (2016), heritage food as passed down from generation to generation plays an essential role as a source of cultural identity in the society. Whether goods, sources of information or symbolism, heritage simultaneously becomes a symbol of identity and a factor of difference for any social group (Ollagnon, 1984). Moreover, Bortolotto and Ubertazzi (2018) mentioned that as part of cultural heritage, food may be very important for certain groups or communities living in certain areas, so it is very important that this heritage is preserved. This research, like many others in the qualitative studies, has limitations. The sample size and data are insufficient to reflect the whole of Kedah traditional food population. Needless to say, in order to learn further about heritage cuisine in the future, more in-depth study from many locations and perspectives are required, since this is a large topic with many facets to investigate. Similarly, the literature has yet to create a definition and description of Kedah heritage food for future reference.

\section{Acknowledgment}

This research was funded by Universiti Teknologi MARA through the Research Management Centre (RMC): 600-IRMI 5/3/LESTARI (059/2019)600-IRMI 5/3/LESTARI (059/2019).

\section{Corresponding Author}

Noriza Ishak

Faculty of Hotel and Tourism Management, Universiti Teknologi MARA Selangor, Puncak Alam Campus, Selangor.

Email: noriz267@uitm.edu.my

\section{References}

Abdullah, K. M., Ismail, F. H., Zamzuri, N. H., Aziz, S. A. A., \& Muhamad, R. (2020). Pahang food terminologies: Young generations' understanding and usage.J. Tour. Hosp. Culin. Arts, 12, 485-493.

Abdullah, K. M., Mohamad, R., Zahari, M. S. M., \& Sharif, M. S. M. (2016). Malay cooking method terminologies: understanding and usage. In Proceedings of the ASEAN Entrepreneurship Conference 2014 (pp. 265-274). Springer, Singapore.

Ahmat, S. (1957). Kedah-Siam relations, 1821-1905. Journal Malayan Branch Royal Asiatic Society, 30(pt 3), 9-10. 
Almansouri, M., Verkerk, R., Fogliano, V., \& Luning, P. A. (2021). Exploration of heritage food concept, Trends in Food Science \& Technology, 111, 790-797, https://doi.org/10.1016/j.tifs.2021.01.013.

Alonso, A. D., \& Krajsic, V. (2013). Food heritage down under: olive growers as Mediterranean 'food ambassadors'. Journal of Heritage Tourism, 8(2-3), 158-171.

Bessière, J. (1998). Local development and heritage: traditional food and cuisine as tourist attractions in rural areas. Sociologia Ruralis, 38(1), 21-34.

Bessière, J. (2013). 'Heritagisation', a challenge for tourism promotion and regional development: An example of food heritage. Journal of Heritage Tourism, 8(4), 275-291. doi:10.1080/1743873x.2013.770861

Bianchi, S. M., Milkie, M. A., Sayer, L. C., \& Robinson, J. P. (2000). Is Anyone Doing the Housework? Trends in the Gender Division of Household Labor. Social Forces, 79(1), 191-228. 10.2307/2675569

Bortolotto, C., \& Ubertazzi, B. (2018). Foodways as Intangible Cultural Heritage. International Journal of Cultural Property, 25(4), 409-418.

Braddel, D. S. R. (1989). The Study of Ancient Times in the Malay Peninsula and Straits of Melaka. The Malaysian Branch of the Royal Asiatic Society.

Brissenden, R. (2003). South East Asian Food. Hardie Grant Publishing.

Brulotte, R. L., \& Di Giovine, M. A. (Eds.). (2016). Edible identities: Food as cultural heritage. Routledge.

Davallon, J. (2002). Comment se fabrique le patrimoine? Sciences humaines. Hors série(36), 74-77.

Debevec, L., \& Tivadar, B. (2006). Making connections through foodways: contemporary issues in anthropological and sociological studies of food. Anthropological Notebooks. 12 (1), 5- 16.

DiPiazza, J. (2004). Italian-American foodways: A personal and academic look into Sunday Dinner. http://dialogues.rutgers.edu/vol_03/pdf_files/j_dipiazza.pdf

Given, L. M. (2008). The Sage Encyclopedia of Qualitative Research Methods. Los Angeles, Calif.: Sage Publications.

Hakimi, A. J. (2006). Perdagangan dan Perkapalan Melayu di Selat Melaka: Abad ke-15 hingga ke-18. Dewan Bahasa dan Pustaka.

Halid, S. (2016). Kedah kekal negeri jelapang padi. Berita Harian.

Hamzah, H., Karim, M. S., Othman, M., \& Hamzah, A. (2013). Dimensions of authenticity in Malay cuisine from experts' perspectives. Acad J Interdiscip Stud, 2(3): 369e77.

InfoMalaysia (Producer). (2016). Info Malaysia (IIM) Leading Industrial, Commercial, Tourism \& Information in Malaysia. https://www.iim.com.my/state-of-malaysia/aboutkedah.html

Itawrah. (2020). 18 Makanan Tradisional Kedah (Makanan Berasal Dari Kedah WAJIB Cuba). Saji.

Kapelari, S., Alexopoulos, G., Moussouri, T., Sagmeister, K. J., \& Stampfer, F. (2020). Food Heritage Makes a Difference: The Importance of Cultural Knowledge for Improving Education for Sustainable Food Choices. Sustainability, 12(4). doi:10.3390/su12041509

Kedah, L. M. N. (2020). Tentang Kedah. Kedah: Kerajaan Negeri Kedah Darul Aman. https://www.kedah.gov.my/index.php/tentang-kedah.

Kuroda, K. (2015a). Inland People of Kedah; Thai speaker in History. In (pp. 17). 
Kuroda, K. (2015b). A Migrants' World from South Thailand to Kedah: A History of Inland Kedah.: Tokyo University of Foreign Studies Institute for Asian and African Languages and Cultures.

Ling, K. F. (2012). The Food of Asia: Featuring Authentic Recipes from Master Chefs: Tuttle Publishing.

Maclean, D., Andjelkovic, M., \& Vetter, T. (2007). Intangible cultural heritage and sustainable development, Vol. 8

Mahmud, Z. H. (1969). The Pioneering of Wet Rice Growing Traditions in West Malaysia - A Restudy with Special Reference to the State of Kedah. Geographica, 5, 1-7.

Malaysian Department of National Heritage. (2016). Jabatan Warisan Negara. Makanan Warisan. http://www.heritage.gov.my/adat-budaya/makanan-warisan.html

Mardatillah, A., Raharja, S. J, Hermanto, B. \& Herawaty, T. (2019). Riau Malay food culture in Pekanbaru, Riau Indonesia: commodification, authenticity, and sustainability in a global business era. Journal of Ethnic Foods, 6(3).

Misiura, S. (2006). Chapter 5 - The marketing mix and food and drink heritage, Heritage Marketing, Butterworth-Heinemann, 183-237.

Muhammad, N. H., Ab Karim, M. S., \& Hamzah, H. (2015). Intention to eat traditional food among boys and girls in Malaysia. International Journal of Social Science and Humanity, 5(5), 450.

Muhammad, R., Zahari, M. S. M., Shariff, M. S. M., \& Abdullah, K. M. (2016). Malaysian Foodways: Acculturation/Assimilation Towards Authenticity Sustainability among Diasporic Community. Procedia - Social and Behavioral Sciences, 222, 367-373. doi:10.1016/j.sbspro.2016.05.184

Noor, Z. M. (2020). Pekan Rabu lambang kemegahan peniaga Melayu. Utusan Digital.

Ollagnon, H. (1984). Acteurs et patrimoine dans la gestion de la qualité des milieux naturels. Aménagement et nature.

Rahman, S. A. G., Ab Karim, S., Ishak, F. A. C., \& Arshad, M. M. (2018). Understanding The Young Generations'preference Towards Malay Traditional Food In Malaysia. Journal of Tourism, 3(9), 42-57.

Rearick, N. A. (2009). "Food is something that we gather around": Foodway Practices among Arab Americans in Columbus, Ohio (Doctoral dissertation, The Ohio State University).

Rianti, A., Novenia, A. E., Christopher, A., Lestari, D., \& Parassih, E. K. (2018). Ketupat as traditional food of Indonesian culture. Journal of Ethnic Foods, 5(1), 4-9.

Rozin, P. (2006). The integration of biological, social, cultural and psychological influences on food choice. University of Surrey, Guildford, UK: CAB International.

Saad, M., Kamarizzaman, N. A., Ishak, N., \& Pratt, T. J. (2021). The Influence of Pahang Heritage Food on Behavioral Intentions among Malaysian Domestic Tourists. Environment-Behaviour Proceedings Journal, 6(16), 163-169.

Sahari, F., Hasan, R., Durin, A., Adruce, A. Z. S., \& Abdul Rahman, S. (2018). Traditional food wrapping and packaging: Culture and identity of the Saribas Malay, Sarawak. International Journal of Innovative Design, Creativity and Social Sciences, 2(1), 1-7.

Smith, L., \& Akagawa, N. (2008). Intangible heritage: Routledge.

Smith, L. P., Ng, S. W., \& Popkin, B. M. (2013). Trends in US home food preparation and consumption: analysis of national nutrition surveys and time use studies from 19651966 to 2007-2008. Nutr J 12, 45. https://doi.org/10.1186/1475-2891-12-45 
Smith, S. L., Ramey, E., Sisson, S. B., Richardson, S., \& DeGrace, B. W. (2020). The family meal model: Influences on family mealtime participation. OTJR: Occupation, Participation and Health, 40(2), 138-146.

Stubbs, M. (2010). Heritage-sustainability: developing a methodology for the sustainable appraisal of the historic environment. Planning Practice \& Research, 19(3), 285-305. doi:10.1080/0269745042000323229

Tibere, L., \& Aloysius, M. (2013). Malaysia as a food-haven destination: the vision and its sustainability. Asia-Pacific Journal of Innovation in Hospitality and Tourism, 2(1), 37-51.

Ting, H., Tan, R. S., \& John, A. N. (2017). Consumption intention toward ethnic food: determinants of Dayak food choice by Malaysians. J Ethnic Foods, 4, 21-27.

Tokoro, I. (2015). Islam and Cultural Diversity in Southeast Asia.

Tourism Malaysia (Producer). (2014). Pekan Rabu, Kedah. Tourism Malaysia.

Trichopoulou, A., Vasilopoulou, E., Georga, K., Soukara, S., \& Dilis, V. (2006). Kedah heritage food foods: Why and how to sustain them. Trends in Food Science \& Technology, 17(9), 498-504.

Werner, O., \& Schoepfle, G. M. (Eds.). (1987). Systematic fieldwork: Foundations of ethnography and interviewing (1 ed. Vol. 1). USA: SAGE

Yadav, A. (2020). Food Consumption Pattern Among Youth. Journal Global Values, Vol. XI, No.Il Article No. 28, 227- 233. https://anubooks.com/ jgv-vol-xi-no-2-julydec-2020/ https://doi.org/ 10.31995/ jgv.2020.v11i02.028

Zahari, M. M., Sharif, M. M., Noor, N. M., \& Ishak, N. (2013). Malay Kedah heritage food food knowledge and young generation practices. Science Series Data Report, 5(4), 14-24. 